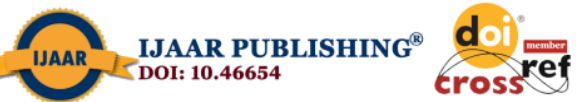

International Journal of Advanced Academic Research (Social and Management Sciences) | ISSN: 2488-9849

Journal DOI: 10.46654/ij.24889849

Vol. 6, Issue 9 (September, 2020) |www.ijaar.org

Article DOI: 10.46654/ij.24889849.s6912

\title{
BRAND EQUITY AND PURCHASE INTENTIONS OF TELECOMMUNICATION FIRMS IN RIVERS STATE OF NIGERIA
}

\author{
HARCOURT Horsfall (Ph.D) \\ Department of Marketing, \\ Rivers State University, Port Harcourt, Nigeria. \\ harcourthorsfall@gmail.com
}

\begin{abstract}
This study investigates the influence of based brand equity on customer's purchase intention of telecommunication firms in Rivers State of Nigerian. The population for this study constitutes customers of four telecommunication firms in Rivers State. The purposive sampling technique was used to select fifty (50) customers of the four telecommunication firms studied. This produced 200 customers as respondents from the four mobile firms under study. A structured questionnaire was used for data gathering, and the copies of the questionnaire sent out were 200, from which 200 responses were received, out of which 178 (89\%) was useful for the study. The analysis was performed with the multiple regression technique; with the aid of the Statistical Package for Social Sciences (SPSS) version 22.0 findings disclosed that brand equity attributes (brand awareness, brand association, perceived quality and brand loyalty) significantly affect purchase intention. The study therefore, concludes that brand equity significantly and positively influence purchase intentions, and recommends management of telecommunication firms should spotlight more on creating brand awareness to increase purchase intentions. They should also, intensify their brand equity programme to embrace all the components of brand equity to match purchase intention levels.
\end{abstract}

Keywords: Brand equity, Brand awareness, Brand association, Perceived quality, Brand loyalty, Purchase intention. 


\section{INTRODUCTION}

Brand equity is an important concept in marketing because of its viability to create value for both customers and the company, and through which marketers can achieve competitive advantage over competitors (Chen \& Chang, 2008). The unsympathetic competition in the business landscape compels firms to initiate competitive strategies in order to set apart their products from other competitors to achieve success in the market. Achieving success in the market place requires competent tools for magnetizing, maintaining, and increasing the consumers' loyalty. Companies use brand equity in setting distinct goal of attracting their consumers' attention by focusing on any physical properties (e.g., taste, design) or unphysical (e.g., price, brand name and country of origin) (Hadi\& Azim, 2011). The brand equity connotes that component of a product that is concerned to the brand. It is the insubstantial and indispensable possessions of a firm which is attained through the customers' attitudes and behavior. A brand is a name, term, sign, symbol, design or indication mishmash that is projected to categorize the goods and services of one firm or group of firms (Kotler \& Armstrong, 2010; Aaker, 1991). Customers for the most part frequently utilize and are disposed to pay higher prices for branded products when they have the occasion to decide on other products that fall into the same category (Pappu, Quester \& Cooksey, 2005).

Keller (2003) defined brand equity as 'the differential effect of brand knowledge on consumer response to the marketing of the brand' and brand knowledge is a major precursor of customer based brand equity. It is in turn conceptualized as a brand node in memory to which a multiplicity of associations has been connected. The conceptualizations of brand equity have principally emerged from cognitive psychology and information economics (Rahman, Angeles \& Lambkin, 2018).From the standpoint of cognitive psychology, the customer based brand equity transpires when consumers embrace some complimentary, physically powerful, and inimitable brand associations in memory, which in turn leads to incremental effectiveness or value added. Accordingly, endowment in brand equity is predictable to pilot and give a high degree of difference in consumer response that may optimistically involve compact worth. Ultimately, the value of a brand is derived in the market through the actions of consumers. The study of its outcomes has become, therefore, an urgent and challenging task (Torres, Bijmolt, Tribó, \&Verhoef, 2012; Vomberg Homburg, \& Bornemann, 2014).

The prevailing rivulet of investigation has been stranded in cognitive psychology, spotlighting on recall configuration (Christodoulides \& De Chernatony, 2010). Therefore, this study is an added tread in this bearing, and it proposes and tests a model to better appreciate brand equity and investigate the effects of this construct on purchase intention using data from customers of four telecommunication firms in Rivers State of Nigeria. This study proposes causal relations among the four brand equity dimensions. The existence of a hierarchy among brand equity dimensions has been postulated in the literature (Yoo \& Donthu, 2001; Keller \& Lehmann, 2006, 2003).

The study is organized as follows: It opens with a brief, general discussion of brand equity. The conceptual model and hypotheses are presented. The methodology is after that described tagged on by the analysis and empirical findings. The paper then delineates the conclusions, implications and limitations of the study. 


\section{Brand Equity}

Brand equity has its origins in cognitive psychology (Keller, 2002; Aaker, 1996) as a measure of the enduring results realized by the outlays prepared in the formation and intensification of brands. The progression of brand equity can be portrayed as a consumer learning process where consumers' awareness of the brand demonstrate the way to attitudes (e.g. perceived quality and brand associations), which subsequently influence attitudinal brand loyalty (Konecnik \& Gartner, 2007; Gordon et al., 1993). Brand equity characterizes the consumers' perceptions and attitudes towards it.Aaker (1991) identified the dimensions of brand equity as brand awareness, brand associations, perceived quality and brand loyalty. These four dimensions of brand equity stand for consumer perceptions and responses to the brand. This study adopts the four dimensions of brand equity in the study.

\section{Brand Awareness}

Brand awareness is the opening tread to crafting brand equity. This dimension refers to whether consumers can bring to mind or be familiar with a brand and is linked to the potency of a brand's existence in consumers' minds (Aaker, 1996). Keller (2003:17) defines brand awareness as "the customers' ability to recall and recognize the brand as reflected by their ability to identify the 13 brand under different conditions and to link the brand name, logo, symbol, and so forth to certain associations in memory". Harcourt and Ikegwuru (2018) remark that brand awareness is a significant determinant which can be recognized in most replica of branding. Brand awareness entails connecting the brand to dissimilar associations in memory (Keller, 2003), hence, consumers must initially be aware of a brand to soon after have a deposit of brand associations (Aaker, 1991). Brand awareness impinges on the configuration and the power of brand associations, together with perceived quality (Pike et al., 2010; Keller \& Lehmann, 2003).

\section{Brand Association}

Brand association comprises of the entire brand allied mind-set, thoughts, images, beliefs, experiences, attitudes as well as the whole lot linked with the brand (Kotler \& Keller, 2006). Brand associations are the notions that have relations to the brand name in consumer memory (Keller \& Lehmann, 2006). According to Aaker (1992), brand association is the most timehonored aspect of branding. They correspond to rationale for settling on to purchase and enclosing loyalty for brand. Chen (2001) noted that two types of brand associations exist and they are organization association and products associations.

\section{Perceived Quality}

Perceived quality is an added dimension analyzed in branding (Feldwick, 2006) fairly than been analyzed as component of the general brand association. Perceived quality refers to the discernment of the general quality or pre-eminence of a product or service comparative (Keller, 2003). Perceived quality denotes how the customer evaluates the entire pre-eminence or distinction of a product or service that is unusual from its objective quality, which Anselmsson et al. (2007) refer to as the quantifiable, practical and its confirmable nature, procedure and quality controls. An elevated objective quality does not automatically affix any worth to brand equity. As noted by Keller and Lehmann (2003), perceived quality and brand 
associations symbolize the precursor stride leading to brand loyalty. Towering altitude of perceived quality and affirmative associations can increase brand loyalty (Pike et al., 2010; Keller \& Lehmann, 2003).

\section{Brand Loyalty}

Brand loyalty is perceived as a nucleus breadth of quantifying corporate brand. Brand loyalty is the connection a consumer has to a brand (Aaker, 1991). Brand loyalty is the affection or profound dedication to a brand (Aaker, 1991). When consumers attain a more affirmative perception of a brand, loyalty emerges, and when they become more attached to a brand, they are expected to uphold close nearness with the brand since the existence of the connection object presents mind-set of relief, cheerfulness, and protection (Park et al., 2010). Brand loyalty consists of Behavioral loyalty and cognitive loyalty. Behavioral loyalty is distinguished where customer behavior in the market place points toward a quantity of frequent purchases or the dedication to repurchase the brand as a crucial choice. Cognitive loyalty comes up when in a necessity to make a purchase decision; a brand springs up earliest in the customer's intellect or a customer's initial choice.

\section{Purchase Intention}

Purchase intention is intimately linked to consumers' policy in making genuine purchase in definite period of time (Howard, 1991). It can equally be described as the push for or spur emanating from consumers' minds to purchase a definite brand following their evaluation, before choosing to put together any purchase as relates to their needs, attitudes, and perceptions in the direction of the brands (Madahi \& Sukati, 2012). Purchase intention is a multi-step route (Tariq Nawaz, Nawaz, Butt, 2013), where initially, consumers accumulate any associated information concerning their preferred brand, and begin to appraise it by means of its characteristics given that they have experienced the product and have absolute product information regarding the product. Hosein (2012) states that, consumers purchase intention can be measured by means of interest, attending, and information. Interest is consumers' mind-set in the direction of a brand that influences them to purchase. Attending is the turnout of consumers in exposition and other sustaining events that sways them to purchase. Information is any supplementary knowledge and facts regarding the brand drawn together by the consumers and make them reflect on to purchase it.

Durianto and Liana (2004) measured purchase intention as a decisive dynamic to know and envisage consumer behavior. Purchase intention operates as an essential dynamic influencing the authentic ultimate purchase and possibly will show the way to repeat buying in the future (Pi et al., 2011; Pavlou \& Gefen, 2004). Purchase intention from existing buyers is more to envisage consumers' satisfaction and potential transactions once the consumers discovers that the brands go well with them and merit buying (Madahi \& Sukati, 2012).

Harcourt and Ikegwuru (2018) studied the relationships flanked by four dimensions of brand equity and market performance (customer acquisition) by means of data drawn through questionnaire from 54 executives of food and beverage firms in Rivers State and 236 academic staff of three tertiary institutions of learning in Rivers State (236). The instruments 
were validated by means of Cronbach alpha's test, upon which all variables exceed the yardstick 0.7. Data was analyzed by using the Pearson's Products Moment Correlation Coefficient (PPMC), ANOVA and regression analysis procedures. It was found that, all the dimensions of brand equity studied were critical at $\mathrm{P}<(0.05)$ (one tailed) in shaping the behaviour of customer acquisition. Particularly, brand awareness was found to have the most decisive statistical interface with market performance, trailed by perceived quality, brand loyalty and brand association. Moreover, there is a significant difference between the opinions of food and beverage firms and end customers in the estimation of market performance. The study therefore, concludes that, brand equity significantly influence market performance. The study recommends amongst others that management of food and beverage firms should key in three dimensions of brand equity (brand awareness, perceived quality and brand loyalty) to customer acquisition, since the study reveals that there is a statistically significant relationship between them.

Joo-Eon (2017) examined the relationships between brand concepts and brand equity through the mediating roles of emotional attachment and customer commitment, and empirically demonstrates the important contribution of the three-brand concept to customer commitment and to brand equity that has been envisaged by previous research. The chief input of the study is to exhibit the effects of the brand concepts linked to aesthetic, functional and symbolic benefits on brand equity. Hence, brand equity may be sighted as a connect in the pathway of effects that ultimately join brand concepts with market performance. Brand concept, emotional attachment and customer commitment are applicable constructs underlying brand equity, and commitment and loyalty are major intervening variables in relational interactions.

Santoso and Cahyadi (2014) analyze the impact of brand equity towards purchase intention in automobile industry by means of Aaker's brand equity theory, casing brand awareness, brand association, perceived quality, and brand loyalty. The population is Surabaya people who own or used to own both $\mathrm{ABC}$ and $\mathrm{XYZ}$ cars. The study used the simple random sampling technique in which 125 samples were collected and analyzed using Multiple Linear Regression Analysis and comparative analysis. The result demonstrates that brand equity concurrently has a significant influence on purchase intention while only brand association and brand loyalty independently have a significant influence towards purchase intention. From the comparative analysis, $\mathrm{ABC}$ has a better brand association than $\mathrm{XYZ}$, but a lower brand loyalty than XYZ.

Buil, Martı'nez and de Chernatony (2013) looked at the effects of brand equity on consumers' responses using data from two European countries. The structural equation modeling (SEM) was employed. Measurement inconsistency and inflexibility of the model across the two national samples was appraised by means of multi-group confirmatory factor analysis. The results show that brand equity dimensions interconnect. Brand awareness positively influence perceived quality and brand associations. Brand loyalty is mainly affected by brand associations. As a finishing summit, perceived quality, brand associations and brand loyalty are the foremost drivers of all-purpose brand equity. The results further authenticate the positive effect of brand equity on consumers' responses. What is more, the general arrangement predicted is found to be rationally energetic across the intended countries. However, understanding of the phenomenon of brand equity requires use of all areas of equity, these include all the dimensions of brand equity as factors affecting company's value and market value, and to gain new customers and retain. Therefore, this 
study investigate the influence of customer-based brand equity and purchase intention of telecommunication firms in Rivers State.

Based on the review of literature, the following research null hypotheses were formulated to guide the study.

Ho. Brand awareness does not significantly influence purchase intention.

$\mathbf{H o}_{2}$. Brand association does not significantly influence purchase intention.

Ho. Perceived quality does not significantly influence purchase intention.

Ho. Brand loyalty does not significantly influence purchase intention.

\section{METHODOLOGY}

This research aims to analyze the influence of brand equity elements on purchase intention in telecommunication firms in Rivers State of Nigeria. The research design adopted for this study is correlation. Correlational research design is a survey method that indicates the magnitude or strength and nature or direction of linear relationship that exists between two or more variables or set of data in a single group of subjects (Kpolovie, Joe \& Okoto, 2014 cited in Kayii \& Okiridu, 2020) The population of the study constitutes customers of four major telecommunication firms (MTN, Globacom, Airtel and 9Mobile) in Port Harcourt, Rivers State. The population is chosen as this research aims to identify the brand equity of these telecommunication firms. This study used purposive sampling; a non-probability sampling to select fifty (50) customers each from the four telecommunication firms studied. This produced two hundred (200) respondents or samples among the population. The researcher distributed questionnaires to those who attend or come to the telecommunication firms' offices.

A total of 200 questionnaires were completed. Non-valid questionnaire were discarded, resulting in 178 valid questionnaire. Giving a response rate of $89 \%$. Since the objective of this study is to analyze the effect of the influence of the elements of brand equity on purchase intention, the multiple linear regression analysis was used.

\section{RESULTS AND DISCUSSION}

\section{Reliability Analysis}

Reliability Coefficient was worked out for the multiple scale and each of the subscales, and the results are reported in table 1. As we can see, the value of the Alpha coefficient for the composite scale and the subscales exceed the threshold $(\alpha \geq 0.70)$; hence, they are all reliable. Table 1 shows the reliability assessment of our predictor variables using Cronbach's alpha. It specifies how the items for each factor were internally related in the manner expected. 
Table 1. Validity Statistic of Consumer-Based Brand Equity and Purchase Intention $(\mathbf{n}=\mathbf{1 7 8})$

\begin{tabular}{lccc}
\hline Scale & Dimension & Items & Reliability \\
\hline BAW & Brand Awareness & 5 & 0.862 \\
BAS & Brand Association & 5 & 0.848 \\
PQ & Perceived Quality & 5 & 0.816 \\
BL & Brand Loyalty & 5 & 0.822 \\
Overall Reliability Scale & & 15 & 0.886 \\
\hline
\end{tabular}

Source: SPSS 22.0 Window output (based on 2020 field survey data).

Table1 outlines the reliability result of consumer-based brand equity and purchase intention, which also contains the individual item reliability test. Appreciably, all items are reliable and were used to investigate consumer-based brand equity and purchase intentionof telecommunication firms in Rivers State, Nigeria. The extent of the relationship between consumer-based brand equity and purchase intention can be operationalised using brand awareness (.862) with 5-items measure; brand association (.848) with a 5-item measure; perceived quality (.816), and brand loyalty (.822). According to Ghozali (2013), the indicators are well thought-out as reliable to represent the variables when the value of Cronbach's Alpha is higher than 0.7.

\section{Test of Hypotheses}

The study used the multiple regression analysis, and paid attention on the result of Adjusted R2, F-test and t-test. Coefficient of determination or Adjusted R2 measures how well the regression model explains or turns the variation of dependent variable (Ghozali, 2013). The nearer Adjusted R2 value to 1, the better the independent variables can predict the dependent variable. The F-test chiefly illustrates whether all independent variables used in the regression model concurrently have impacts on the dependent variable (Ghozali, 2013). The study used $95 \%$ confidence level in which the significance level is $5 \%$.

Table 2: ANOVA Table

\begin{tabular}{|c|c|c|}
\hline $\begin{array}{r}\text { R2 } \\
\text { t-test }\end{array}$ & F-test & Sig. \\
\hline $\begin{array}{l}\text { Regression } \\
5.928\end{array}$ & 24.535 & .0000 \\
\hline
\end{tabular}

Source: SPSS 22.0 Window output (based on 2020) 
Table 2 shows whether the independent variables concurrently have an influence on the dependent variable. From the F-test shown in table 1, it can be seen that the significance F in the Sig. line confirms value of 0.000 , which implies it is lower than 0.05 significance level. Besides; the F value illustrated in table 1 is 24.535 , which is higher than $\mathrm{F}$ table (2.6795). Accordingly, it can be implied that $\mathrm{HO}$ is rejected, demonstrating that there is a concurrent influence of the independent variables (the components of consumer-based brand equity) on the dependent variable (purchase intention). The result of this research shows brand equity concurrently has an influence on purchase intention, which is in support with the earlier applicable inquiries (Astuti\&Kurnianto, 2013; Agusli\&Sondang, 2013).

Table 3: Effects of individual Independent Model

\begin{tabular}{lcccc} 
Model & \multicolumn{2}{l}{ Unstandardized } & & \\
& \multicolumn{2}{c}{ Coefficients } & $\mathbf{t}$ & Sig. \\
(Constant) & B & Std, Error & & \\
(Constant) & 0.67 & 0.874 & 0.121 & 0.02 \\
BA W & 0.94 & 204.85 & 19.9261 & 0.00 \\
BAS & 0.89 & 0.423 & 19.9812 & 0.00 \\
PQ & 0.74 & 170.97 & 19.9490 & 0.00 \\
BL & 0.81 & 351.35 & 18.5987 & 0.00
\end{tabular}

Source: SPSS 22.0 Window output (based on 2020 field survey data).

Table 3 shows the effect of individual independent variables on the dependent variable. According to t-test, individual variable (brand awareness, brand association, perceived quality, and brand loyalty) has a significant influence on the dependent variable (purchase intention) when the significant $t$ is less than significance level (0.05) and t-test statistic value is greater than or lower than \pm table $( \pm 1.979)$. As depicted in table 3, brand awareness, brand association, perceived quality and brand loyalty have significant influence on purchase intention as the $t$-critical values are greater than 1.979 and significance $t$ is lower than 0.05 . Hence, it can be asserted that elements of brand equity are established to individually have a significant influence on purchase intention of telecommunication firms. This finding is in line with previous related studies (Astuti \& Kurnianto, 2013; Jalilvand, Samiei \& Mahdavinia, 2011) which found that all components of brand equity individually have a significant influence on purchase intention.

Table 4. Adjusted R Square Test

\begin{tabular}{llcrc} 
& $\mathbf{R}$ & $\mathbf{R} 2$ & Adjusted R2 & Std Error of the Estimate \\
Model 1 & .992 & .985 & .980 & 204.85 \\
\hline
\end{tabular}

Source: SPSS 22.0 Window output (based on 2020 field survey data). 
Table 4 illustrates the regression model explanations of the variation of dependent variable. The higher the value of adjusted R2, the better the independent variables in explaining the dependent variable. From table 2, it can be distinguished that the adjusted R Square is 0.980 . This indicates that $98.0 \%$ of the variance in purchase intention of telecommunication firms can be explained by the variance of the components of brand equity (brand awareness, brand association, perceived quality, and brand loyalty), considering the sample size and independent variables. Moreover, this also indicates that there are $2.0 \%$ other factors that cannot be explained in this study but have significant influence on purchase intention in the telecommunication firms.

\section{CONCLUSION}

The study collected 200 questionnaires; however, only 178 questionnaires are valid and used for the study. The outcome of the reliability and validity test illustrate that all pointers engaged in the study are reliable and valid. The overall aim was to determine whether telecommunication firms' brand equity show the way to purchase intention relate to the dimensions of brand equity. Based on the multiple regression test, brand equity (brand awareness, brand association, perceived quality, and brand loyalty) concurrently have significant influence on purchase intention. Moreover, brand awareness has the most critical influence on purchase intention. This is followed by brand association, perceived quality and brand loyalty. The study therefore, concludes that brand equity has significant influence on purchase intentions of telecommunication firms in Rivers State of Nigeria.

\section{RECOMMENDATIONS}

From the finding of this study,

i. It is recommended that management of telecommunication should spotlight more on creating brand awareness to increase purchase intentions.

ii. They should also, intensify their brand equity programme to embrace all the components of consumer-base brand equity to match purchase intention levels. 


\section{REFERENCES}

Aaker, D.A. (1991). Managing brand equity. Capitalizing on the value of brand name, The Free Press, New York, NY.

Aaker, D.A. (1996). Measuring brand equity across products and markets. California Management Review, 38 (3), 102-20

Agusli, D. \& Sondang, Y. (2013). Analisa Pengaruh Dimensi Ekuitas Merek Terhadap Minat Beli Konsumen Midtown Hotel Surabaya. Journal Strategi Pemasaran, 1(2), 1--8.

Astuti, B., \& Kurnianto, E. (2013). Analisis Pengaruh Komponen Pembentuk Ekuitas MerekTerhadap Minat Beli. Proceeding Seminar Nasional Dan Call For Papers Sancall 2013.

Buil, I., Mart1'nez, E. \& de Chernatony, L. (2013). The influence of brand equity on consumer responses. Journal of Consumer Marketing 30(1), 62-74.

Chaudhuri, A. (1995). Brand equity or double jeopardy? Journal of Product and Brand Management, 4 (1), 26-32.

Chen, C., \& Chang, Y (2008). Airline brand equity, brand preference, and purchase intentions-The moderating effects of switching costs. Journal of Air Transport Management, 14: 40-42.

Christodoulides, G. \& De Chernatony, L. (2010). Consumer-based brand equity conceptualization and measurement. International Journal of Market Research 52: $43-66$.

Cobb-Walgren, C., Ruble, C.A. \&Donthu, N. (1995). Brand equity, brand preference and purchase intent. Journal of Advertising, 24(3), 25-40.

Durianto, D. \& Liana, C. (2004). Analisisefektivitasiklantelevisi softener soft \& fresh di jakarta dansekitarnyadenganmenggunakanconsumen decision model, Journal Ekonomi Perusahaan, 11 (1), 35-55.

Ghozali, I. (2013). Aplikasi Analisis Multivariate dengan Program IBM SPSS 21 Update PLS Regresi (7th ed.). Semarang: Badan Penerbit Universitas Diponegoro.

Gordon, G.L., Calantone, R.J. \& di Benedetto, C.A. (1993). Brand equity in the business-tobusiness sector. Journal of Product and Brand Management, 2(3), 4-16.

Harcourt, H. \&Ikegwuru, M.K. (2018). Brand equity and market performance: An empirical study of food and beverage firms in Rivers State. IIARD International Journal of Economics and Business Management, 4(4), 1-14.

Hoeffler, S. \& Keller, K.K. (2003). The marketing advantages of strong brands. Brand Management, 10(6), 42-45. 
Hosein, N. Z. (2012). Measuring the purchase intention of visitors to the Auto Show. Journal Of Management \& Marketing Research, 9.

Howard, J. A. (1994). Buyer behavior in marketing strategy. Englewood Cliffs, N.J.: Prentice Hall.

Jalilvand, Samiei, N. \&Mahdavinia, S. H. (2011). The effect of brand equity components on purchase intention: an application of Aaker's model in the automobile industry. International Business \& Management, 2 (2).

Joo-Eon, J. (2017). The impact of brand concept on brand equity. Asia Pacific Journal of Innovation and Entrepreneurship, 11(2). 233-245.

Kayii, N.E \&Okiridu, O.F (2020). Teachers' Perception toward the Integration of Soft Skills in Teaching Business Studies in Secondary Schools in Rivers State.Vocational and Technology Education Journal (VOTEJ, 2(1), 39-48.

Keller, K.L. (2003), Strategic Brand Management: Building, Measuring, and Managing Brand Equity, (2nd ed.). Prentice Hall, New York, NY.

Keller, K.L. \& Lehmann, D.R. (2003). How do brands create value? Marketing Management, May/June, 27-31.

Keller, K.L. \& Lehmann, D.R. (2006). Brands and branding: research findings and future priorities. Marketing Science, 25 (6), 740-59.

Konecnik, M. \& Gartner, W.C. (2007). Customer-based brand equity for a destination. Annals of Tourism Research, 34 (2), 400-21.

Kotler, P. \& Armstrong, G. (2010). Principles of Marketing, Pearson Education, Upper Saddle River, NJ.

Lassar, W., Mittal, B. \& Sharma, A. (1995). Measuring customer-based brand equity. Journal of Consumer Marketing, 12(4), 11-19.

Madahi, A. \&Sukati, I. (2012). The effect of external factors on purchase intention amongst young generation in Malaysia. International Business Research, 5 (8).

Netemeyer, R., Krishnan, B., Pullig, C., Wang, G., Yagci, M., Dean, D., Ricks, J. \& Wirth, F. (2004). Developing and validating measures of facets of customer-based brand equity. Journal of Business Research, 57,209-24.

Pavlou, P.A. \&Gefen, D. (2004). Building effective online market places with institution based trust. Information Systems Research, 15 (1), 37-59.

Pi, S., Liao, H.L., Liu, S.H. \& Lee, I.S., (2011). Factors influencing the behavior of online group buying in Taiwan. Journal of Business Management, 5 (16), 7120- 7129. 
Pike, S., Bianchi, C., Kerr, G. \& Patti, C. (2010), "Consumer-based brand equity for Australia as a longhaul tourism destination in an emerging market. International Marketing Review, 27 (4), 434-49.

Pappu, R., P.G. Quester, R.W. Cooksey, 2005. Consumer-based brand equity: improving the measurement -empirical evidence. Journal of Product \& Brand Management, 14(3), 143-154.

Rahman, M., Ángeles Rodríguez-Serrano, M. \& Lambkin, M. (2018). Brand management efficiency and firm value: An integrated resource based and signaling theory perspective. Industrial Marketing Management, 72,112-26.

Santoso, C.R. \& Cahyadi, T.E. (2014). Analyzing the impact of brand equity towards purchase intention in automotive industry: A case study of ABC in Surabaya. iBuss Management, 2(2), 29-39.

Seitz, V., Razzouk, N. \& Wells, D.M. (2010). The importance of brand equity on purchasing consumer durables: an analysis of home air-conditioning systems. Journal of Consumer Marketing, 27(3), 236-42.

Tariq, M., Nawaz, M., Nawaz, M., \& Butt, H. (2013). Customer perceptions about branding and purchase intention: A study of FMCG in an emerging market. Journal of Basic and Applied Scientific Research, 3(2), 340--347.

Torres, A. Bijmolt, T.H.A., Tribó, J.A, \&Verhoef P (2012). Generating global brand equity through corporate social responsibility to key stakeholders. International Journal of Research in Marketing, 29(1), 13-24.

Vomberg, A., Homburg, C., \&Bornemann, T (2014). Talented people and strong brands: The contribution of human capital and brand equity to firm value. Strategic Management Journal, 2(3) 23-49.

Yoo, B. \& Donthu, N. (2001). Developing and validating a multidimensional consumer-based brand equity scale. Journal of Business Research, 52, 1-14. 